\title{
A Dreissena Risk Assessment for the Colorado River Ecosystem
}

By Theodore A. Kennedy

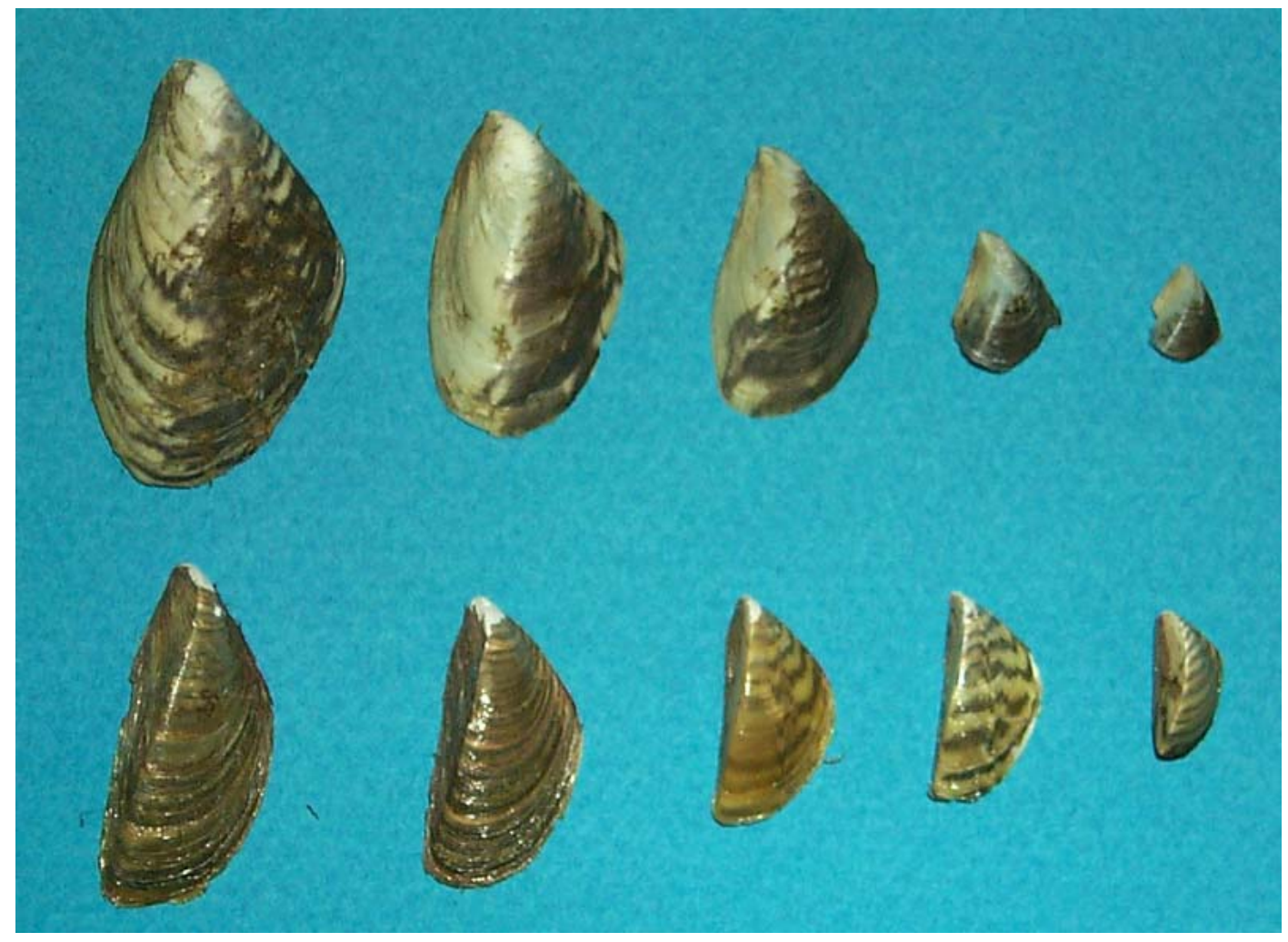

Open-File Report 2007-1085

U.S. Department of the Interior

U.S. Geological Survey 
Cover: Quagga mussels (top row) and zebra mussels (bottom row). Photograph courtesy of the National Oceanic and Atmospheric Administration, Great Lakes Environmental Research Laboratory. 


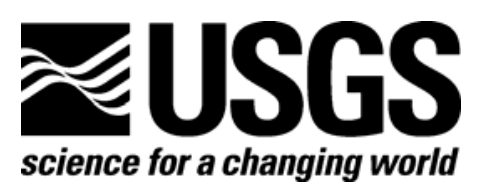

\section{A Dreissena Risk Assessment for the Colorado River Ecosystem}

By Theodore A. Kennedy

Open-File Report 2007-1085

U.S. Department of the Interior

U.S. Geological Survey 


\section{U.S. Department of the Interior DIRK KEMPTHORNE, Secretary}

\section{U.S. Geological Survey \\ Mark D. Myers, Director}

U.S. Geological Survey, Reston, Virginia 2007

For product and ordering information:

World Wide Web: http://www.usgs.gov/pubprod

Telephone: 1-888-ASK-USGS

For more information on the USGS - the Federal source for science about the Earth, its natural and living resources, natural hazards, and the environment:

World Wide Web: http://www.usgs.gov

Telephone: 1-888-ASK-USGS

Suggested citation:

Kennedy, T.A., 2007, A Dreissena risk assessment for the Colorado River ecosystem: U.S. Geological Survey Open-File Report 2007-1085, 17 p.

Any use of trade, product, or firm names is for descriptive purposes only and does not imply endorsement by the U.S. Government.

Although this report is in the public domain, permission must be secured from the individual copyright owners to reproduce any copyrighted material contained within this report. 


\section{Contents}

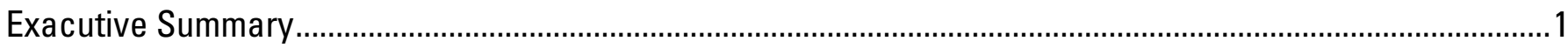

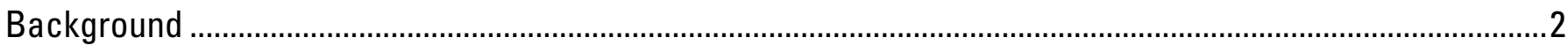

Risk of Dreissena Establishing and Maintaining High Densities ......................................................................

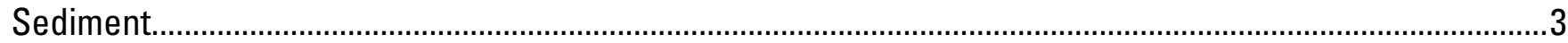

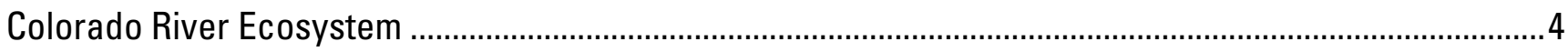

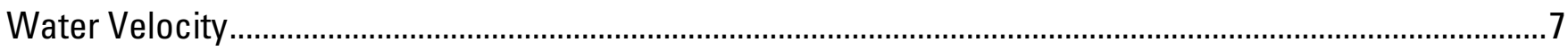

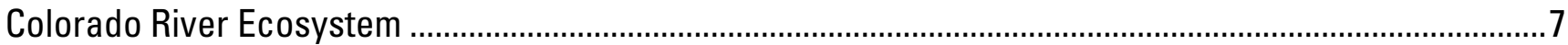

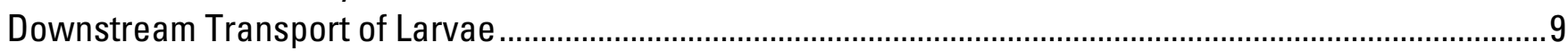

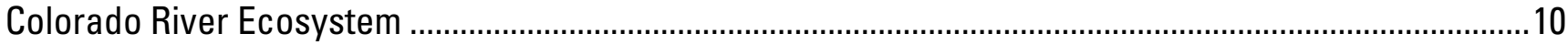

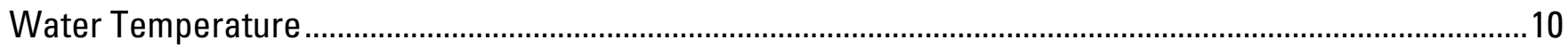

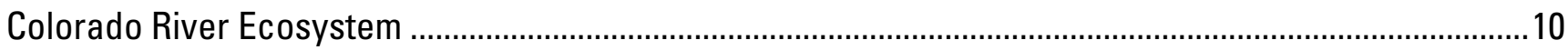

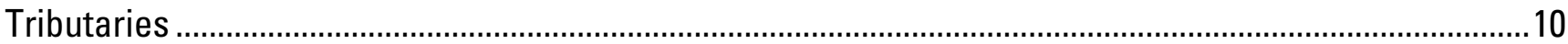

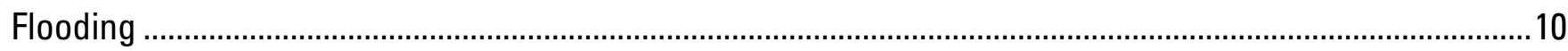

Risk of Ecological Impacts Because of Dreissena.....................................................................................11

Lake Powell and Glen Canyon Dam Releases ........................................................................................11

Colorado River Ecosystem .................................................................................................................11

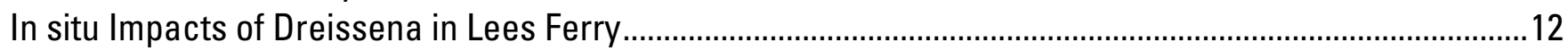

In situ Impacts of Dreissena in the Colorado River Ecosystem ...................................................................13

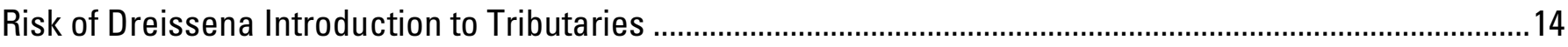

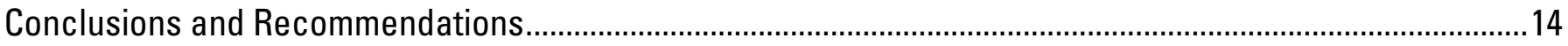

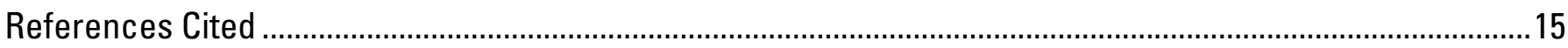

\section{Figures}

1. Quagga mussels (Dreissena bugensis) and zebra mussels (Dreissena polymorpha) .................................. 2

2. Suspended sediment concentrations ( $\mathrm{mg} / \mathrm{L}$ ) for Lees Ferry and mainstem Colorado River ecosystem, 1999-2006

3. Water clearance potential for Dreissena at various densities and filtration rates for Lees Ferry and mainstem Colorado River ecosystem (CRE)

\section{Tables}

1. Concentrations of suspended inorganic sediment, suspended particulate organic matter, and inorganic:organic (l:0) ratios for Lees Ferry and regions of the Colorado River ecosystem.................6

2. Concentrations of suspend inorganic sediment, particulate organic matter, and inorganic:organic (I:0) ratios for the Colorado River ecosystem 


\section{Conversion Factors}

\begin{tabular}{lll}
\hline \multicolumn{1}{c}{ Multiply } & \multicolumn{1}{c}{ By } & \multicolumn{1}{c}{ To obtain } \\
\hline Length & & \\
\hline millimeter $(\mathrm{mm})$ & 0.03937 & $\begin{array}{l}\text { inch (in.) } \\
\text { foot }(\mathrm{ft})\end{array}$ \\
meter $(\mathrm{m})$ & 3.281 & mile (mi) \\
kilometer $(\mathrm{km})$ & 0.6214 & \\
\hline Area & & square foot $\left(\mathrm{ft}^{2}\right)$ \\
\hline square meter $\left(\mathrm{m}^{2}\right)$ & 10.76 & \\
\hline Volume & & quart (qt) \\
\hline liter $(\mathrm{L})$ & 1.057 & foot per second (ft/s) \\
\hline Flow rate & & gallon per minute (gal/min) \\
\hline meter per second (m/s) & 3.281 & \\
liter per second (L/s) & 15.85 & ounce, avoirdupois (oz) \\
\hline Mass & &
\end{tabular}

Temperature in degrees Celsius $\left({ }^{\circ} \mathrm{C}\right)$ may be converted to degrees Fahrenheit $\left({ }^{\circ} \mathrm{F}\right)$ as follows:

${ }^{\circ} \mathrm{F}=\left(1.8 x^{\circ} \mathrm{C}\right)+32$

Concentrations of chemical constituents in water are given either in milligrams per liter (mg/L) or micrograms per liter $(\mu \mathrm{g} / \mathrm{L})$.

NOTE TO USGS USERS: Use of hectare (ha) as an alternative name for square hectometer $\left(\mathrm{hm}^{2}\right)$ is restricted to the measurement of small land or water areas. Use of liter (L) as a special name for cubic decimeter $\left(\mathrm{dm}^{3}\right)$ is restricted to the measurement of liquids and gases. No prefix other than milli should be used with liter. Metric ton (t) as a name for megagram (Mg) should be restricted to commercial usage, and no prefixes should be used with it. 


\title{
A Dreissena Risk Assessment for the Colorado River Ecosystem
}

\author{
By Theodore A. Kennedy
}

\section{Executive Summary}

Nonnative zebra and quagga mussels (Dreissena polymorpha and Dreissena bugensis, respectively; fig. 1) were accidentally introduced to the Great Lakes in the 1980s and subsequently spread to watersheds of the Eastern United States (Strayer and others, 1999). The introduction of Dreissena mussels has been economically costly and has had large and far-reaching ecological impacts on these systems. Quagga mussels were found in Lakes Mead and Havasu in January 2007. Given the likelihood that quagga mussels and, eventually, zebra mussels will be introduced to Lake Powell and the Colorado River at Lees Ferry, it is important to assess the risks that introduction of Dreissena mussels pose to the Colorado River ecosystem (here defined as the segment of river from just below Glen Canyon Dam to Diamond Creek; hereafter CRE). In this report, I assess three different types of risks associated with Dreissena and the CRE: (1) the risk that Dreissena will establish at high densities in the CRE, (2) the risk of ecological impacts should Dreissena establish at high densities in the CRE or in Lake Powell, and (3) the risk that Dreissena will be introduced to tributaries of the CRE.

The risk of Dreissena establishing within the CRE is low, except for the Lees Ferry tailwater reach where the risk appears high. Dreissena are unlikely to establish at high densities within the CRE or its tributaries because of high suspended sediment, high ratios of suspended inorganic:organic material, and high water velocities, all of which interfere with the ability of Dreissena to effectively filter feed. The rapids of Grand Canyon may represent a large source of mortality to larval Dreissena, which would limit their ability to disperse and colonize downstream reaches of the CRE. In contrast, conditions within the Lees Ferry tailwater generally appear suitable for Dreissena establishment, with the exception of high average water velocity.

If Dreissena establish within the CRE, the risks of negative ecological impacts appear low. If Dreissena are able to attain moderate densities in Lees Ferry, estimates of filtration capacity indicate they are unlikely to substantially alter the composition (e.g., nutrient concentrations, suspended organic matter concentrations) of water exported from Lees Ferry. Further, a moderate density of Dreissena within Lees Ferry may actually increase food available to fishes by increasing habitat complexity and stimulating benthic production. If Dreissena attain moderate densities in the CRE mainstem, which seems unlikely, ecological impacts will probably be comparable to Lees Ferry - an increase in benthic production. Dreissena may have ecological impacts on the CRE, if they become established in Lake Powell and substantially alter the composition of water released from Glen Canyon Dam; however, it is unclear whether changes in the composition of water released from Glen Canyon Dam will have a net positive or negative impact on food availability in the CRE mainstem. 
The risk of Dreissena introduction to tributaries appears low. None of the tributaries have upstream lakes or reservoirs that could actually serve as a source population for Dreissena; reservoirs on the Little Colorado River may eventually support Dreissena, but they are far up in the watershed and the segment of river connecting them with the mainstem CRE is intermittent. If the CRE mainstem is colonized by Dreissena, there are no significant vectors for transporting them upstream into the tributaries. In addition, lethally high summer water temperatures make it unlikely that Dreissena will establish in many tributaries.

Lake Powell is a logical focus for management and research efforts, given that maintenance of Dreissena populations within the CRE will require an upriver source population and the uncertainty associated with the downstream impact of changes in Lake Powell water quality.

\section{Background}

Nonnative zebra and quagga mussels (Dreissena polymorpha and Dreissena bugensis, respectively; fig. 1) were accidentally introduced to the Great Lakes in the 1980s and subsequently spread to watersheds of the Eastern United States (Strayer and others, 1999). The introduction of Dreissena mussels has been economically costly and has had large and far-reaching ecological impacts on many freshwater ecosystems.

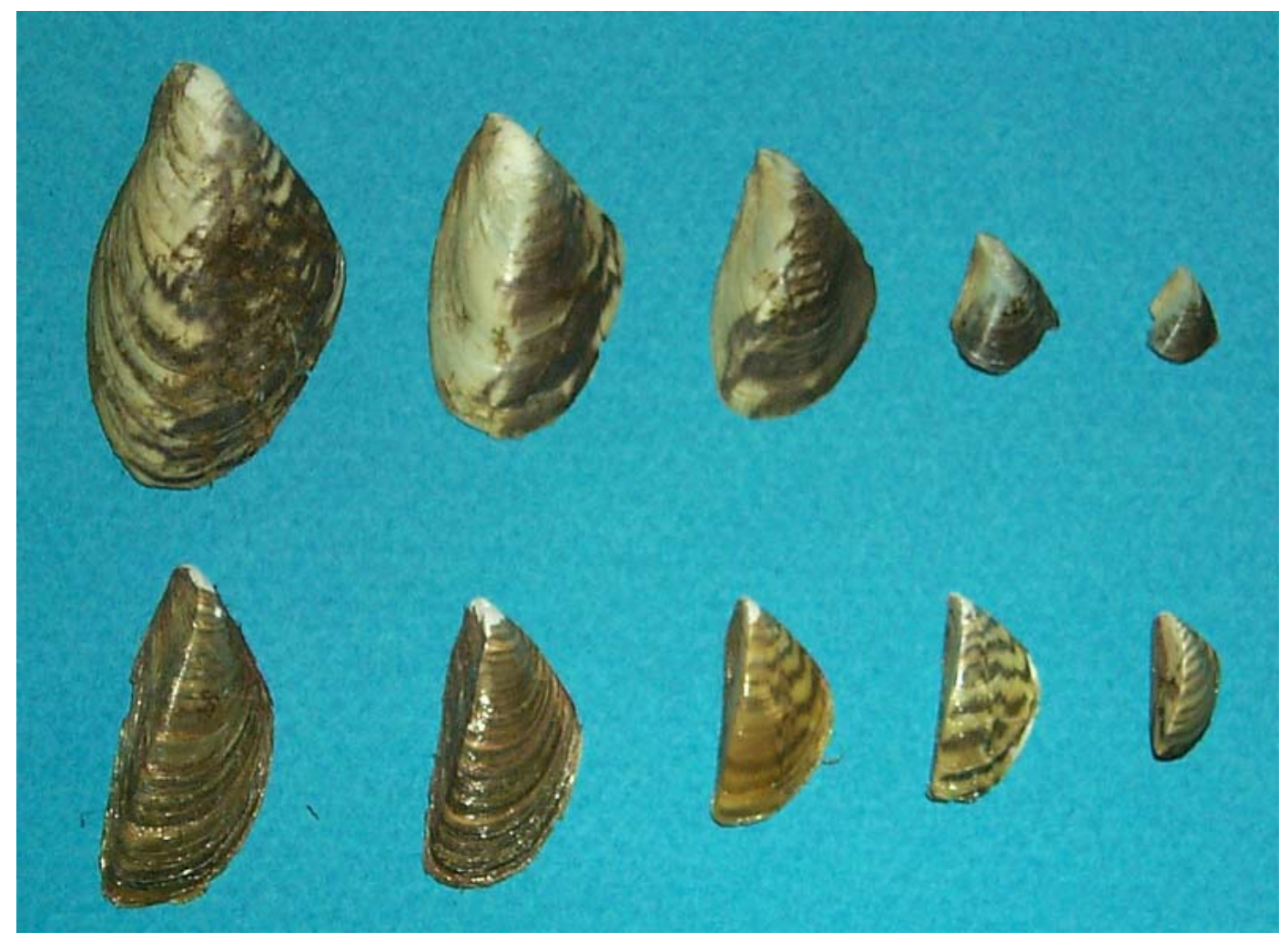

Figure 1: $\quad$ Quagga mussels (Dreissena bugensis, top row) and zebra mussels (Dreissena polymorpha, bottom row). Photograph courtesy of the National Oceanic and Atmospheric Administration, Great Lakes Environmental Research Laboratory. 
The major ecological impacts of Dreissena introductions in the Eastern United States have been large declines in the density, and possible extinctions, of native mussels and a diversion of energy resources in lakes and rivers from the water column to the benthos (i.e., lake or river bottom substrata). Declines in the density of native mussels following Dreissena invasion result from the overgrowth of native mussels by Dreissena, and possibly negative effects of competition for limited food resources (Ricciardi and others, 1998; Strayer and Malcom, 2007). Dreissena have diverted resources from the water column because of their tremendous capacity to filter water (Strayer and others, 1999); zebra mussels in the Hudson River estuary completely filter the water column once every 1 to $4 \mathrm{~d}$. Filter feeding by Dreissena mussels has led to large declines in phytoplankton and zooplankton density and increases in water clarity (Strayer and others, 1999). Increases in water clarity, coupled with the nutrient-rich feces and pseudofeces that Dreissena excrete on the benthos, has shifted primary production in Dreissena infested rivers and lakes from the water column to the benthos. Consequently, Dreissena infested rivers and lakes generally support higher densities of benthic algae and macrophytes, such as the filamentous alga Cladophora, and higher densities of benthic invertebrates, including amphipods like Gammarus, relative to lakes and rivers where Dreissena are absent (Beekey and others, 2004; Bially and MacIsaac, 2000; Botts and others, 1996; Greenwood and others, 2001; Stewart and others, 1998; Strayer and others, 1998). Increases in the density of benthic invertebrates associated with Dreissena invasion appear to be because of both increases in habitat complexity and benthic primary production; Dreissena shells and the nutrient-enriched microenvironment around them make for habitat that supports higher densities of benthic invertebrates relative to the unstable and sandy substrates they replaced (Botts and others, 1996). The Dreissena induced shift in the location of food resources (from the water column to the benthos) appears to have led to shifts in the abundance or distribution of fishes. Strayer and others (2004) report that following Dreissena invasion of the Hudson River, populations of "open-water" species that feed on zooplankton decreased by a median value of $28 \%$, while populations of "littoral" species (those that reside near the shore, where zebra mussel beds occur) that feed on benthic invertebrates increased by a median value of $97 \%$. Thus, the reduction in "open-water" fish species has been offset by increases in "littoral" species leading to no net change in fish abundance or biomass.

Quagga mussels were found in Lake Mead and Lake Havasu in January 2007. The primary vector of mussel transport among watersheds is recreational watercraft (Johnson and others, 2001; Leung and others, 2006). Because the number of recreational watercraft moving from Lakes Mead and Havasu to Lake Powell and the Colorado River above and below Glen Canyon Dam is high, the introduction of quagga mussels into the Colorado River below Glen Canyon Dam is likely. The Colorado River in Grand Canyon supports populations of federally endangered humpback chub (Gila cypha) and the Lees Ferry tailwater supports an important rainbow trout (Oncorhynchus mykiss) fishery. Because Dreissena introductions to lakes and rivers of the Eastern United States have led to broad ecosystem-scale changes, it is important to assess the risks that the introduction of Dreissena poses to the ecosystem below Glen Canyon Dam.

The following is a Dreissena risk assessment for the Colorado River ecosystem (CRE), which is here defined as the segment of river from just below Glen Canyon Dam to Diamond Creek, including tributaries. I will assess risks for the Lees Ferry reach (just below Glen Canyon Dam to Lees Ferry; hereafter Lees Ferry reach), the mainstem CRE (from Lees Ferry to Diamond Creek; hereafter mainstem CRE), and major tributaries of the Colorado River (e.g., Paria River, Little Colorado River, Bright Angel Creek, etc.; hereafter tributaries) separately. I assess risks posed by Dreissena mussels in general, not just quagga mussels, because it is likely that zebra 
mussels will be introduced to the system at some point in the future, habitat requirements and impacts of zebra and quagga mussels are generally similar (though I will note differences between species where they have been documented), and the literature on zebra mussels is more extensive than quagga mussels. I assess three different types of risk associated with Dreissena mussels and the CRE: (1) the risk that Dreissena mussels will establish at high densities in the CRE, (2) the risk that Dreissena mussels will have ecological impacts on the CRE, and (3) the risk that Dreissena will be introduced to tributaries (I assume that risk of introduction to the CRE mainstem and Lees Ferry is extremely high). I will also discuss how installation of a temperature control device on Glen Canyon Dam might affect the risks of Dreissena establishment.

\section{Risk of Dreissena Establishing and Maintaining High Densities}

The risk of Dreissena establishing and maintaining high densities in the CRE and its tributaries is low, except for the Lees Ferry reach where the risk seems high. The risk of Dreissena establishing and maintaining high densities in the mainstem CRE is low principally because of the high inorganic-sediment concentrations, the high ratio of inorganic:organic suspended particles (I:O ratio), high water velocities within the mainstem CRE, and turbulence in rapids. Dreissana are unlikely to establish and maintain high densities in tributaries because of high I:O ratios, high baseflow water velocities, periodic floods that mobilize the bed, and lethally high summer water temperatures $\left(>25^{\circ} \mathrm{C}\right)$. High water velocities may limit the ability of Dreissena to attain high densities within Lees Ferry, but otherwise this reach appears suitable for Dreissena. The bases for these conclusions are detailed below.

\section{Sediment}

High sediment concentrations and high inorganic:organic ratios are likely to limit the ability of Dreissena to establish and maintain high densities in the mainstem CRE. Studies by MacIsaac and Rocha (1995), Madon and others (1998), and Schneider and others (1998) all found zebra mussels' ability to feed and grow is severely compromised, or nonexistent, at high concentrations of suspended sediment or high ratios of inorganic:organic particles. MacIsaac and Rocha (1995) found that production of pseudofeces and, to a lesser extent, feces by zebra mussels increased with increasing concentrations of suspended clay. Pseudofeces are suspended particles that have been filtered by a mussel but are expelled from the animal before they are ingested. Production of pseuodofeces appears to be a mechanism whereby Dreissena mussels can preferentially select higher quality food items. If filtered particles are dominated by inorganic sediment, they are likely to be rejected as pseudofeces, but if filtered particles contain predominantly organic matter they are likely to be ingested and then excreted in the form of feces. Production of pseudofeces requires the expenditure of energy by the mussel, so preferential selection of higher quality particles comes at an energetic cost to the animal. The implications of this study are that as sediment concentrations increase, mussels must reject more and more of what they filter in the form of pseudofeces, at a cost to their overall energy balance.

The study by Madon and others (1998) found that a variety of zebra mussel feeding and growth indices were strongly and negatively correlated with increasing inorganic-sediment concentrations and increasing ratios of inorganic:organic particles. Specifically, Madon and others (1998) report that clearance rates (the amount of water filtered per mussel per hour), ingestion rates (the amount of food particles actually ingested per mussel per hour), and assimilation efficiency (the efficiency at which ingested food particles were assimilated by the mussel) all declined sharply 
at suspended-sediment concentrations above $1 \mathrm{mg} / \mathrm{L}$. Assimilation efficiency was $0 \%$ at sediment concentrations of $100 \mathrm{mg} / \mathrm{L}$, regardless of the I:O ratio. They also found exponential declines in clearance rates, ingestion rates, and assimilation efficiencies with increasing I:O ratios. Further, Madon and others (1998) report that scope for growth (the ability of zebra mussels to grow-the balance between energy gained via assimilation and energy expended during feeding and maintenance) for zebra mussels was negative at I:O ratios above 1.71. Simply put, Madon and others (1998) found that zebra mussels cannot sustain positive growth when the mass of suspended sediment exceeds the mass of particulate organic matter by a factor of 1.71. The organic matter fed to zebra mussels in this study was a slurry of phytoplankton, high-quality organic matter because of its high nitrogen and phosphorus content. Schneider and others (1998) used natural Illinois River water and natural Illinois River water augmented with a slurry of phytoplankton in their study, and found basically the same results as Madon and others (1998); zebra mussel scope for growth was negative at I:O ratios exceeding 2.

In contrast to the above experimental studies, several studies have found that high suspended-sediment concentrations do not completely limit the ability of Dreissena to establish in rivers (Allen and Ramcharan, 2001; Allen and others, 1999; Sprung, 1993; Thorp and others, 1998). Allen and Ramcharan (2001) found that ionic conditions (i.e., calcium concentrations), but not sediment, determined whether zebra mussels were able to successfully establish in rivers where they were known to have been introduced. Allen and others (1999) found that zebra mussels were able to maintain positive growth on an annual basis in the lower Mississippi River despite sediment concentrations that were high throughout the year (mean of $100 \mathrm{mg} / \mathrm{L}$ ). Trefry and others (1994) sporadically measured suspended-sediment and organic-matter concentrations for the Mississippi River from 1974 to 1991 and found average sediment concentrations were $98 \mathrm{mg} / \mathrm{L}$ and organic matter represented $2.66 \%$ of total suspended particulates - this is equivalent to an I:O ratio of 37. The lowest I:O ratio observed by Trefry and others (1994) was 13.0. Thorp and others (1998) found that turbidity, a proxy for sediment concentration, had no appreciable effect on Dreissena survival or growth, but sediment concentrations were not measured, so it is not possible to interpret the results of their research in the context of the CRE. Regardless, all of these studies indicate Dreissena are in fact capable of establishing in environments that have high suspended-sediment concentrations and high I:O ratios, but the experimental studies clearly indicate that Dreissena density is going to be limited in systems with high sediment loads, which will limit their potential for ecological impacts. For example, I spoke with several scientists working in the lower Mississippi River and, although none of them could provide me with an estimate of zebra mussel density, they all agreed that zebra mussel densities there are low and ecological impacts are therefore negligible (Dr. John Lynn, Dr. Robert McMahon, personal communications).

\section{Colorado River Ecosystem}

Concentrations of suspended sediment in the CRE mainstem indicate that Dreissena scope for growth may be negative for much of the year (fig. 2, table 1). Madon and others (1998) found that potential for growth drops sharply at suspended-sediment concentration above $1 \mathrm{mg} / \mathrm{L}$ and was zero/negative at concentrations above $100 \mathrm{mg} / \mathrm{L}$. Since 1999, when regular measurements of suspend sediment in the CRE mainstem were initiated, concentrations of less than $1 \mathrm{mg} / \mathrm{L}$ have not been measured and concentrations have been above $100 \mathrm{mg} / \mathrm{L}$ for significant amounts of time (fig.

2). It should be noted that this record is from sediment samples that were collected at regular intervals, along with event-based sampling. In other words, the data in figure 2 are weighted towards times of high sediment concentrations. Sediment concentrations were measured 
sporadically from 1991-2000 by Yard (p.123; 2003). Although concentrations greater than 100 $\mathrm{mg} / \mathrm{L}$ were not observed as frequently by Yard (2003; table 1) relative to the apparent frequency of their occurrence in figure 2, concentrations less than $1 \mathrm{mg} / \mathrm{L}$ were never observed by Yard in the mainstem CRE and the majority of values were above $10 \mathrm{mg} / \mathrm{L}$. It should be noted that sand (defined as inorganic particles greater than $63 \mu \mathrm{m}$ in size) can represent a significant portion of suspend sediment in the CRE during certain time periods. Studies by MacIsaac and Rocha (1995), Madon and others (1998), and Schneider and others (1998) evaluated the effects of silt/clay (particles less than $63 \mu \mathrm{m}$ in size) on Dreissena feeding and growth metrics. Although sand is larger than the particles that Dreissena typically consumes, which means it may be easier for Dreissena to reject these particles than clay/silt that are similar in size to preferred foods, high concentrations of sand may actually cause abrasion and physically damage the feeding structures of Dreissena (Dr. Robert McMahon, personal communication).

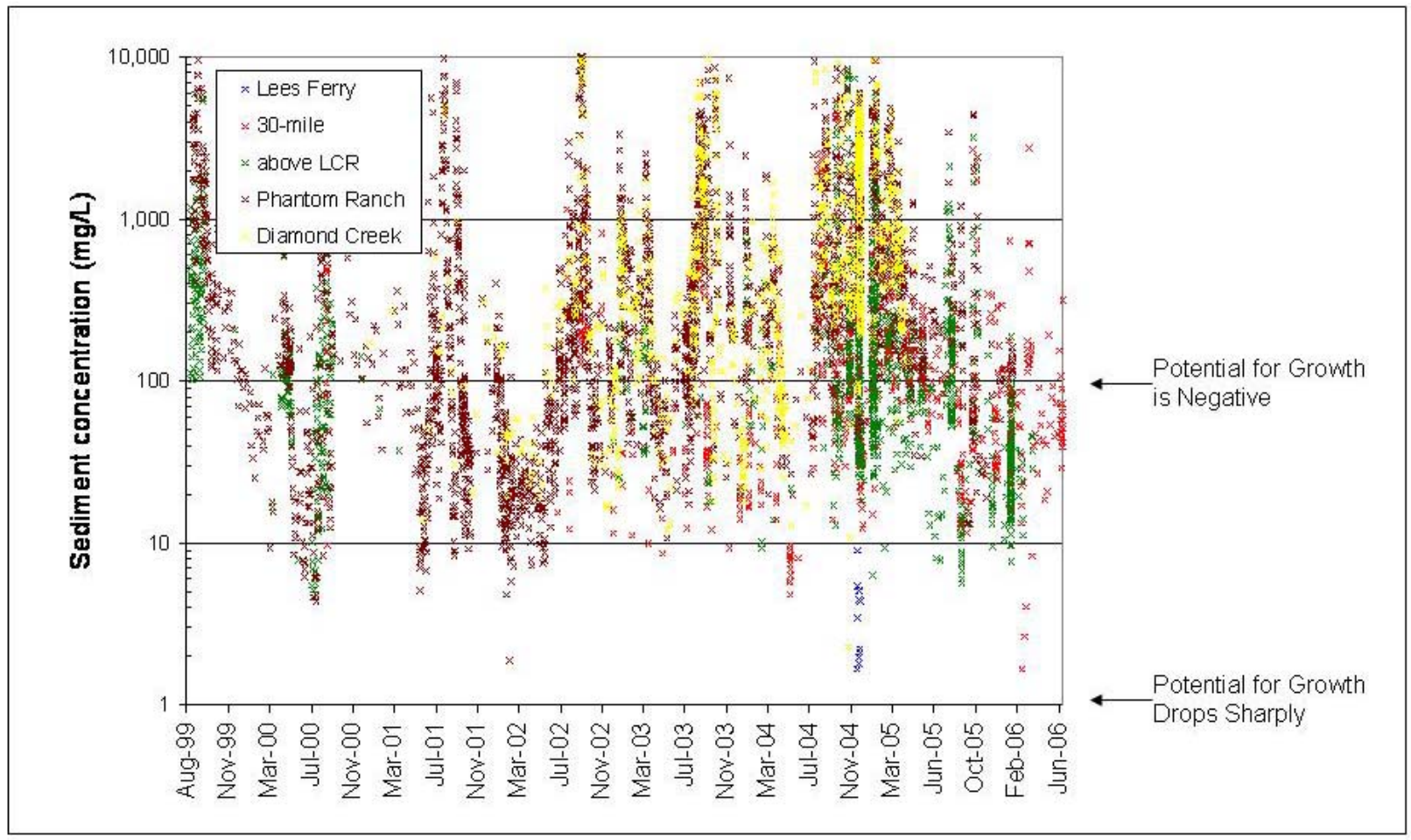

Figure 2. Suspended sediment concentrations $(\mathrm{mg} / \mathrm{L})$ for Lees Ferry and mainstem Colorado River ecosystem, 1999-2006. 
Table 1. Concentrations of suspended inorganic sediment, suspended particulate organic matter, and inorganic:organic (l:0) ratios for Lees Ferry and regions of the Colorado River ecosystem. I:0 ratios in red text are $>1.7$, indicating Dreissena growth potential is likely to be negative (Madon and others, 1998). Lees Ferry encompasses river miles (RM) - 15 to 0, Marble Canyon is RM 0 to 61, central Grand Canyon is RM 61 to 144, and western Grand Canyon is RM 144 to 225. Data are from Yard (2003).

\begin{tabular}{|c|c|c|c|c|c|c|}
\hline Location & Date & $0\left(\mathrm{~m}^{3} / \mathrm{s}\right)$ & $\mathbf{n}$ & Inorganic (mg/L) & Organic (mg/L) & 1:0 \\
\hline Lees Ferry & June-July 1991 & 142 & 9 & 2 & 8 & 0.3 \\
\hline Lees Ferry & May-June 1994 & 227 & 8 & 5.2 & 1.2 & 4.3 \\
\hline Lees Ferry & August 2000 & 227 & 3 & 1.3 & 0.8 & 1.6 \\
\hline Lees Ferry & May 1991 & 425 & 6 & 1.4 & 3.7 & 0.4 \\
\hline Lees Ferry & May 1998 & $300-540$ & 6 & 0.3 & 0.6 & 0.5 \\
\hline Lees Ferry & May 1999 & $410-620$ & 18 & 2.1 & 1.1 & 1.9 \\
\hline Lees Ferry & May-June 1992 & $160-400$ & 12 & 1.4 & 2.6 & 0.5 \\
\hline Lees Ferry & August 1998 & $340-675$ & 3 & 0.5 & 2 & 0.3 \\
\hline Lees Ferry & August 1999 & $410-660$ & 3 & 1.1 & 0.2 & 5.5 \\
\hline Median & & & & 1.4 & 1.2 & 0.5 \\
\hline Marble Canyon & June-July 1991 & 142 & 14 & 3 & 6.8 & 0.4 \\
\hline Marble Canyon & May-June 1994 & 227 & 20 & 8.7 & 1.9 & 4.6 \\
\hline Marble Canyon & August 2000 & 227 & 24 & 2.6 & 1.2 & 2.2 \\
\hline Marble Canyon & May 1991 & 425 & 14 & 7.7 & 6.1 & 1.3 \\
\hline Marble Canyon & May 1998 & $300-540$ & 59 & 6.4 & 1 & 6.4 \\
\hline Marble Canyon & May 1999 & $410-620$ & 48 & 92.4 & 3.1 & 29.8 \\
\hline Marble Canyon & May-June 1992 & $160-400$ & 51 & 347 & 31 & 11.2 \\
\hline Marble Canyon & August 1998 & $340-675$ & 44 & 38.7 & 1.7 & 22.8 \\
\hline Marble Canyon & August 1999 & $410-660$ & 46 & 66.1 & 2.3 & 28.7 \\
\hline Median & & & & 8.7 & 2.3 & 6.4 \\
\hline Central Grand Canyon & June-July 1991 & 142 & 21 & 8.3 & 6.2 & 1.3 \\
\hline Central Grand Canyon & May-June 1994 & 227 & 20 & 10.8 & 2 & 5.4 \\
\hline Central Grand Canyon & August 2000 & 227 & 54 & 6.2 & 1.5 & 4.1 \\
\hline Central Grand Canyon & May 1991 & 425 & 27 & 36.4 & 11.7 & 3.1 \\
\hline Central Grand Canyon & May 1998 & $300-540$ & 48 & 48.6 & 2.3 & 21.1 \\
\hline Central Grand Canyon & May 1999 & $410-620$ & 54 & 403 & 7.1 & 56.8 \\
\hline Central Grand Canyon & May-June 1992 & $160-400$ & 64 & 417 & 33.3 & 12.5 \\
\hline Central Grand Canyon & August 1998 & $340-675$ & 57 & 151 & 6.2 & 24.4 \\
\hline Central Grand Canyon & August 1999 & $410-660$ & 60 & 4501 & 205 & 22.0 \\
\hline Median & & & & 48.6 & 6.2 & 12.5 \\
\hline Western Grand Canyon & June-July 1991 & 142 & 18 & 16.3 & 9.3 & 1.8 \\
\hline Western Grand Canyon & May-June 1994 & 227 & 21 & 16.7 & 1.2 & 13.9 \\
\hline Western Grand Canyon & August 2000 & 227 & 69 & 16 & 2.2 & 7.3 \\
\hline Western Grand Canyon & May 1991 & 425 & 24 & 66 & 17 & 3.9 \\
\hline Western Grand Canyon & May 1998 & $300-540$ & 48 & 50.7 & 2.2 & 23.0 \\
\hline Western Grand Canyon & May 1999 & $410-620$ & 53 & 180 & 4.7 & 38.3 \\
\hline Western Grand Canyon & May-June 1992 & $160-400$ & 60 & 183 & 28.7 & 6.4 \\
\hline Western Grand Canyon & August 1998 & $340-675$ & 62 & 228 & 9.8 & 23.3 \\
\hline Western Grand Canyon & August 1999 & $410-660$ & 69 & 4914 & 190 & 25.9 \\
\hline Median & & & & 66.0 & 9.3 & 13.9 \\
\hline
\end{tabular}


Suspended-sediment concentrations in Lees Ferry are unlikely to strongly limit the ability of Dreissena to establish and maintain high densities there (table 1); sediment concentrations $<1$ mg/L are normal for Lees Ferry.

The I:O ratio of suspended particles in the mainstem CRE and its tributaries also indicate that Dreissena scope for growth will be negative for much of the year (table 1). Recall that Madon and others (1998) report that Dreissena scope for growth is negative at I:O ratios above 1.7. Of the nine time periods when Yard (2003; table 1) calculated I:O ratios, seven of those taken in Marble Canyon, eight in central Grand Canyon, and nine in western Grand Canyon were above the 1.7 threshold reported by Madon and others (1998). Recent measurements of I:O ratios $(n=22)$ along the mainstem CRE during 2006-07 show the same pattern (table 2). The I:O ratio in tributaries during base-flow conditions was measured in April and June 2006 (Kennedy and others, unpublished data). The median I:O ratio for all tributaries and dates was 10.1, the minimum was 2.3, and the maximum was 24 . These data indicate that tributaries are not well suited for Dreissena establishment.

The I:O ratio of suspended particles is unlikely to limit the ability of Dreissena to establish in Lees Ferry (tables 1 and 2) because I:O ratios $<1.7$ are regularly observed in Lees Ferry.

\section{Water Velocity}

The high water velocities typical of the mainstem CRE and Lees Ferry are also likely to limit the ability of Dreissena to establish and maintain high densities (Ackerman, 1999). Ackerman (1999) investigated the effect of velocity on the filter feeding of both zebra and quagga mussels and found that both species reacted similarly to flow. Moderate water velocity $(0.1 \mathrm{~m} / \mathrm{s})$ led to increases in the filtration rates of mussels relative to stagnant flows ( 0 and $\sim 0.03 \mathrm{~m} / \mathrm{s}$ ), but higher water velocities $(0.2 \mathrm{~m} / \mathrm{s})$ resulted in lower filtration rates than those observed under even stagnant conditions. Specifically, filtration rates were around $0.06 \mathrm{~L} / \mathrm{mussel} / \mathrm{hr}$ at stagnant/low velocities, $\sim 0.135 \mathrm{~L} / \mathrm{mussel} / \mathrm{hr}$ at moderate velocity, but only $\sim 0.025 \mathrm{~L} / \mathrm{mussel} / \mathrm{hr}$ at the highest velocity tested, $0.2 \mathrm{~m} / \mathrm{s}$. Ackerman (1999) concluded that moderate water velocities lead to increases in filtration rates because of the increased rate of particle delivery to the filtration structures (i.e., their 'mouth' becomes full quicker), but higher velocities actually interfered with the functioning of these filtration structures. The unimodal response of bivalve feeding to increasing water velocity, where filtration rates peak at moderate velocities and then decline or stop at higher velocities, has been observed in a variety of freshwater and saltwater taxa (Ackerman, 1999, and references therein).

\section{Colorado River Ecosystem}

Graf (1995) found that across a range of discharge, average water velocity for the 360-kmlong mainstem CRE is $0.98 \mathrm{~m} / \mathrm{s}$. Within the channel, particularly along the shorelines, there will be refuges where water velocity is lower than $0.98 \mathrm{~m} / \mathrm{s}$. Regardless, it is likely that large segments of the mainstem CRE will be unsuitable for Dreissena because of high water velocities that interfere with their ability to filter feed. This will limit the total abundance that Dreissena can attain in the CRE, which will limit their potential for large ecological impacts. Graf (1995) found that water velocity in Lees Ferry ranges from 0.3 to $1 \mathrm{~m} / \mathrm{s}$, depending on discharge; high water velocities may even limit Dreissena in the clearwater Lees Ferry reach. Water velocity data for tributaries are scant. However, all tributaries are high gradient and likely to have water velocities that limit or prevent Dreissena from filter feeding. For example, water velocity for the Little Colorado River 
Table 2. Concentrations of suspend inorganic sediment, particulate organic matter, and inorganic:organic (l:0) ratios for the Colorado River ecosystem. l:0 ratios in red text are $>1.7$, indicating Dreissena growth potential is likely to be negative (Madon and others, 1998). Kennedy and others, unpublished data.

\begin{tabular}{|c|c|c|c|c|}
\hline River Mile & Date & Inorganic (mg/L) & Organic (mg/L) & I:0 ratio \\
\hline-15 & Apr-06 & trace & 0.53 & $<0.1$ \\
\hline-15 & Jun-06 & trace & 0.44 & $<0.1$ \\
\hline-15 & Jul-06 & 0.32 & 0.35 & 0.88 \\
\hline-15 & Sep-06 & trace & 0.34 & $<0.1$ \\
\hline-15 & Oct-06 & 1.05 & 0.52 & 2.00 \\
\hline-15 & Nov-06 & 0.90 & 0.47 & 1.86 \\
\hline-15 & Dec-06 & 0.88 & 0.42 & 2.03 \\
\hline Median & & 0.32 & 0.44 & 0.88 \\
\hline 0 & Apr-06 & 1.12 & 0.48 & 2.54 \\
\hline 0 & Jun-06 & 0.04 & 0.95 & 0.13 \\
\hline 0 & Jul-06 & 0.75 & 0.48 & 1.49 \\
\hline 0 & Aug-06 & 1.26 & 0.38 & 3.72 \\
\hline 0 & Sep-06 & 0.33 & 0.64 & 0.50 \\
\hline 0 & Oct-06 & 2.13 & 0.52 & 4.12 \\
\hline 0 & Nov-06 & 0.40 & 0.51 & 0.79 \\
\hline 0 & Dec-06 & 0.79 & 0.47 & 1.70 \\
\hline Median & & 0.77 & 0.50 & 1.59 \\
\hline 30 & Apr-06 & 86.65 & 8.32 & 11.69 \\
\hline 30 & Jun-06 & 5.14 & 1.11 & 4.45 \\
\hline 30 & Sep-06 & 809.44 & 71.89 & 11.27 \\
\hline Median & & 86.65 & 8.32 & 11.27 \\
\hline 62 & Apr-06 & 46.14 & 1.88 & 30.18 \\
\hline 62 & Jun-06 & 14.22 & 2.81 & 5.18 \\
\hline 62 & Sep-06 & 2826.41 & 83.98 & 12.40 \\
\hline Median & & 46.14 & 2.81 & 12.40 \\
\hline 125 & Apr-06 & 18.83 & 1.02 & 25.89 \\
\hline 125 & Jun-06 & 11.42 & 1.40 & 7.71 \\
\hline Median & & 15.13 & 1.21 & 16.80 \\
\hline 165 & Apr-06 & 29.81 & 2.78 & 10.23 \\
\hline 165 & Jul-06 & 31.08 & 2.61 & 11.93 \\
\hline 165 & Sep-06 & 212.02 & 17.73 & 12.01 \\
\hline Median & & 31.08 & 2.78 & 11.93 \\
\hline 225 & Apr-06 & 33.80 & 1.57 & 29.61 \\
\hline 225 & May-06 & 10.76 & 1.85 & 5.87 \\
\hline 225 & Jul-06 & 72.23 & 4.12 & 17.89 \\
\hline 225 & Aug-06 & 4927.00 & 110.33 & 44.68 \\
\hline 225 & Sep-06 & 183.68 & 29.82 & 6.16 \\
\hline 225 & Oct-06 & 858.71 & 53.71 & 16.05 \\
\hline 225 & Dec-06 & 141.20 & 10.76 & 18.76 \\
\hline Median & & 141.20 & 10.76 & 17.89 \\
\hline
\end{tabular}


near the confluence with the Colorado River averages $0.41 \mathrm{~m} / \mathrm{s}$ at base flow (USGS gage 09402300, period of record is 1990-present).

\section{Downstream Transport of Larvae}

Cold water temperatures, the short residence time of water in the CRE, and high rates of larval mortality in rapids are all likely to limit the ability of larval Dreissena exported from Lake Powell to colonize the CRE. Because Dreissena veligers (larvae) are free floating during the 1 to 4 weeks required for their development (Sprung, 1993), they are displaced downstream in environments with unidirectional flow (Bobeldyk and others, 2005; Horvath and Lamberti, 1999; Horvath and others, 1996; Stoeckel and others, 2004). Maintenance of Dreissena populations in a stream or river requires the presence of upriver sites that support self-recruiting populations of Dreissena that can serve as a source for veligers (Horvath and others, 1996; Stoeckel and others, 2004). Even with an upstream source population, the density of Dreissena in streams and rivers declines with distance from the source population (Bobeldyk and others, 2005; Horvath and Lamberti, 1999; Horvath and others, 1996; Schneider and others, 2003). This is because of high rates of larval mortality in rivers (Horvath and Lamberti, 1999; Rehmann and others, 2003) and the fact that populations in rivers are generally not self recruiting (Bobeldyk and others, 2005; Horvath and others, 1996; Schneider and others, 2003). That is, because streams and rivers are marginal habitat for Dreissena, an upstream lake or reservoir usually supplies the overwhelming majority of larvae that successfully establish in the river and mortality of those larvae is high enough that the population density declines with distance from the source population.

Larvae must attain a size of $>0.2 \mathrm{~mm}$ before they settle and transition to the adult life stage, and the time required to attain this size is strongly dependent on temperature (Sprung, 1993). Larvae in $24^{\circ} \mathrm{C}$ water may take as little as $8 \mathrm{~d}$ to reach this size threshold, while larvae in $10^{\circ} \mathrm{C}$ water may take as long as 4 weeks to attain this size (Sprung, 1993). Thus, in the case of a river that is dependent on an upstream source population for colonization, only those larvae that can attain a size of $>0.2 \mathrm{~mm}$ while they are in the river will be able to colonize the river; if the residence time of water is short and water temperatures are cold, very few larvae will attain a size of $>0.2 \mathrm{~mm}$ before being exported out of the system.

Turbulence in the rapids of the CRE may lead to higher rates of larval mortality, and thus larger downstream declines in density, relative to other systems that have been studied (Bobeldyk and others, 2005; Horvath and Lamberti, 1999; Horvath and others, 1996; Schneider and others, 2003). Dreissena veligers are highly susceptible to damage from physical forces such as shear stress or turbulence (Horvath and Lamberti, 1999; Rehmann and others, 2003). Horvath and Lamberti (1999) quantified the number of live Dreissena veligers in a lake-outlet stream at various distances from the lake source. They found $90 \%$ of veligers were live immediately below the lake outlet but only 40\% were live $18 \mathrm{~km}$ downstream. Rehmann and others (2003) quantified mortality of veligers exposed to a range of bubble induced turbulence for a period of $24 \mathrm{~h}$. They hypothesized, and then verified, that veliger mortality depended on both the strength of turbulence and the size of the veliger; if the size of the veliger was greater than or equal to the size of the smallest turbulent eddy, then mortality increased significantly, from $\sim 60 \%$ survival at no turbulence to $\sim 30 \%$ survival at the high turbulence treatment. Rehmann and others (2003) reasoned that if turbulent eddies are too large (size of smallest eddy greater than the size of the veliger) they will merely transport veligers, but if turbulent eddies are small, then "velocity gradients exist on a scale small enough to affect larvae.” Rehmann and others (2003) also estimated the size and strength of turbulence present in the stream studied by Horvath and Lamberti (1999) and concluded 
that the degree of veliger mortality those investigators observed can be explained largely by the turbulent energy within the stream.

\section{Colorado River Ecosystem}

The density of Dreissena in the CRE is likely to decline with distance from the dam because cold water temperatures, the short water residence time, and high rates of mortality in rapids will effectively limit the supply of larval Dreissena from Lake Powell. The cold water temperatures in the hypolimnion of Lake Powell and the CRE (Vernieu and others, 2005) will restrict larval Dreissena growth rates. Slow growth rates, and the fact that it only takes $5 \mathrm{~d}$ for water to travel from Glen Canyon Dam to Diamond Creek, will mean that very few larvae exported from Lake Powell will be large enough (i.e., $>0.2 \mathrm{~mm}$ ) to colonize the CRE before they reach Lake Mead. Further, larval mortality in the rapids of Grand Canyon is likely to be high because flow is fully turbulent everywhere (Kieffer, 1987). If exposure to acute turbulence can actually pull apart veligers, as Horvath and Lamberti (1999) suggested, the rapids of Grand Canyon will represent a significant source of mortality for veligers.

\section{Water Temperature}

\section{Colorado River Ecosystem}

Water temperature is unlikely to limit the ability of Dreissena to establish and maintain high densities in the CRE mainstem or Lees Ferry. The range of water temperatures that occur throughout the $\mathrm{CRE}$ is $\sim 5-20^{\circ} \mathrm{C}$ (Vernieu and others, 2005), well within the tolerance limits of both zebra and quagga mussels (Spidle and others, 1995).

Installation of a temperature control device on Glen Canyon Dam is likely to make conditions in the mainstem CRE less suitable for Dreissena. The above assessment indicates that sediment concentrations and I:O ratios, in particular, will severely limit the ability of Dreissena to maintain a positive carbon balance for much of the year. Installation of a temperature control device is predicted to warm summer release temperatures by $\sim 5^{\circ} \mathrm{C}$. Increasing water temperatures will increase respiration rates and energetic demands of mussels, without a concomitant decrease in sediment concentrations, making it even more difficult for them to balance energetic demands.

\section{Tributaries}

Extreme summer water temperatures are likely to prevent Dreissena, quagga mussels in particular, from maintaining populations in many tributaries, including the Paria River, the Little Colorado River, Bright Angel Creek, Kanab Creek, and Havasu Creek. The upper temperature limit for zebra mussels is $\geq 30^{\circ} \mathrm{C}$ and for quagga mussels it is $\sim 25^{\circ} \mathrm{C}$ (Spidle and others, 1995). Maximum summer water temperatures for all of the tributaries listed above exceed $25^{\circ} \mathrm{C}$ (Korn and Vernieu, 1998). Temperatures within the Paria River and Kanab Creek are particularly unsuited for Dreissena, with mean daily temperatures in July and August $\geq 25^{\circ} \mathrm{C}$ and maximum daily temperatures $\geq 32^{\circ} \mathrm{C}$.

\section{Flooding}

Floods are likely to prevent Dreissena from maintaining high densities in tributaries. Bedmobilizing floods occur frequently in the tributaries of Grand Canyon. Even if Dreissena are able 
to establish at high densities in tributaries, floods will undoubtedly reduce the density of, or completely eliminate, Dreissena from these habitats.

\section{Risk of Ecological Impacts Because of Dreissena}

The risk of negative ecological in situ impacts because of Dreissena appears low for Lees Ferry, the mainstem CRE, and tributaries. However, Dreissena could have ecological impacts on the CRE by attaining high densities in Lake Powell and changing the composition (e.g., dissolved nutrients, plankton concentrations, etc.) of water released from Glen Canyon Dam, though largescale impacts seem unlikely (see below). The types of changes to lakes/reservoirs of the Eastern United States that have occurred following Dreissena invasion (e.g., reduction in density of phytoand zooplankton, increase in water clarity and concentration of dissolved nutrients) are likely to increase algae and invertebrate production in Lees Ferry, but the net impact to the mainstem CRE is uncertain. In situ Dreissena impacts on the CRE are contingent on the mussels maintaining high densities, which is possible for Lees Ferry but seems unlikely for the CRE mainstem. If Dreissena maintain high densities in Lees Ferry or the CRE mainstem, liberal estimates of filtration capacity indicate they may be capable of stimulating benthic production, but it seems unlikely that they will substantially alter the concentration of particulate organic matter, which is the food resource for filter-feeding black fly larvae (Simulium spp.) in the CRE. The introduction of Dreissena to the Eastern United States has resulted in large declines and possible extinctions of native freshwater bivalves (Ricciardi and others, 1998; Strayer and Malcom, 2007). The CRE does not support any native species of bivalves.

\section{Lake Powell and Glen Canyon Dam Releases}

It is unlikely that Dreissena in Lake Powell will have a major impact on water released from Glen Canyon Dam. In lakes and reservoirs of the Eastern United States, Dreissena invasions have resulted in declines in phytoplankton and zooplankton density and concomitant increases in water clarity and concentrations of dissolved nutrients (MacIsaac, 1996). However, the largest changes have occurred in shallow water bodies that are not thermally stratified and where the benthic surface area:volume ratio is high; Dreissena can access the entire water column in unstratified systems and their total abundance is high when there is a large benthic surface area (MacIsaac, 1996; Yu and Culver, 1999). Dreissena are unlikely to have a major impact on water released from Glen Canyon Dam because Lake Powell is deep (maximum depth of $157 \mathrm{~m}$ ) and stratified throughout the year (Vernieu and others, 2005), and the benthic surface area:volume ratio is low because the 'shoreline' is a vertical cliff.

\section{Colorado River Ecosystem}

If Dreissena establishment in Lake Powell results in major changes in the composition of water released from Glen Canyon Dam, this will likely result in increased algae and invertebrate production in Lees Ferry, but it is unclear what the net impact will be for the CRE. Reductions in phytoplankton or zooplankton concentrations of release waters are unlikely to have an impact on the Lees Ferry reach because these resources do not appear to play a major role there. In other systems, zooplankton represent a major component of fish diets, particularly for juvenile fishes (Wetzel, 2001). Benthic algae and invertebrates are the dominant food items for rainbow trout in Lees Ferry and zooplankton are rarely eaten (Angradi, 1994; McKinney and Speas, 2001). Filterfeeding black fly larvae are uncommon in Lees Ferry and rarely consumed by fish there. Increases 
in dissolved nutrients associated with Dreissena establishment in Lake Powell should stimulate production of benthic algae in Lees Ferry because it is limited by both nitrogen and phosphorus (Kennedy and others, unpublished data).

Reductions of phytoplankton in release waters may lead to reductions in the density or growth rates of black fly larvae in the CRE, but increases in dissolved nutrients may offset this by stimulating production of algae. Black fly larvae are the dominant food item for many fishes in the mainstem CRE and diatoms represented $\sim 30 \%$ of black fly diets at downstream locations in June 2006 (Holly Wellard, Loyola University Chicago, unpublished data). However, it is unclear whether these diatoms are planktonic and originated in Lake Powell or if they are benthic and originated within the CRE (The Glen Canyon Dam Adaptive Management Program's food base project is currently working to resolve this question.). If these diatoms came from Lake Powell, a reduction in phytoplankton concentrations of release waters could negatively affect growth of black fly larvae far downstream by decreasing their food supply. However, if the concentration of dissolved nutrients in release waters increases, this may stimulate production of benthic algae and invertebrates within the CRE, potentially offsetting declines of black fly larvae associated with reductions of Lake Powell derived phytoplankton.

\section{In situ Impacts of Dreissena in Lees Ferry}

If Dreissena establish at high densities in Lees Ferry, food availability may increase by shifting resources to the benthos and increasing habitat complexity, but estimates of filtration capacity (fig. 3) indicate they are unlikely to substantially alter the concentrations of organic matter exported from Lees Ferry. Figure 3 shows the filtration capacity of Dreissena across a range of mussel densities and filtration rates. At the highest density (10,000 mussels $\left./ \mathrm{m}^{2}\right)$, Driessena will shift substantial resources to the benthos and alter the composition of water exported from the Lees Ferry reach, regardless of the individual filtration rate. At moderate densities (100-1,000 mussels $/ \mathrm{m}^{2}$ ), individual filtration rates will play a large role in determining the magnitude of the effects. Across all filtration rates, it seems likely that moderate densities of mussels in Lees Ferry will increase food availability by shifting resources from the water column to the benthos and increasing habitat complexity. However, it seems unlikely that at moderate densities Dreissena will be capable of substantially altering the concentration of water exported from Lees Ferry; even at a maximum filtration rate of $2 \mathrm{~L} /$ mussel/d and a density of 1,000 mussels $/ \mathrm{m}^{2}$, mussels will only be filtering $12.5 \%$ of the water column by the time it is exported from Lees Ferry. At low densities (110 mussels $/ \mathrm{m}^{2}$ ), Dreissena may increase benthic production by increasing habitat complexity, but it seems unlikely that this effect will be large.

For the purposes of estimating in situ impacts in Lees Ferry, I will use the average density of Dreissena in the Hudson River, $\sim 1,000$ mussels $/ \mathrm{m}^{2}$ (Strayer and others, 1999). I consider this an overestimate given the low water column chlorophyll concentrations $(\sim 1 \mu \mathrm{g} / \mathrm{L})$ and fast average water velocity characteristic of Lees Ferry. Although numerous factors influence individual filtration rates of Dreissena, including mussel size, sediment concentrations, the I:O ratio, and water velocity (Ackerman, 1999; Madon and others, 1998; Schneider and others, 1998), for the purposes of estimating in situ effects in Lees Ferry, I will assume only the effects of water velocity are relevant. Ackerman (1999) reports that at a water velocity of $0.20 \mathrm{~m} / \mathrm{s}$, individual filtration for 11 -mm-long mussels was $0.6 \mathrm{~L} / \mathrm{mussel} / \mathrm{d}$. I will use this value even though it is probably an overestimate, given average water velocity in Lees Ferry ranges from $0.3-1 \mathrm{~m} / \mathrm{s}$. This gives us a liberal estimate of the filtration potential for Dreissena in Lees Ferry of $\sim 6.25 \%$. In other words, a population of Dreissena in the Lees Ferry reach may be capable of filtering $6.25 \%$ of the water 
column by the time it reaches Lees Ferry. Thus, even at what I would consider an overestimate of density and filtration rates, Dreissena in Lees Ferry are unlikely to substantially alter the concentrations of particulate organic matter exported from Lees Ferry. However, Dreissena at these densities and filtration rates are likely to increase the amount of food available for fish by stimulating algae growth with their nutrient-rich feces and excretion products, and increasing habitat complexity for invertebrates.

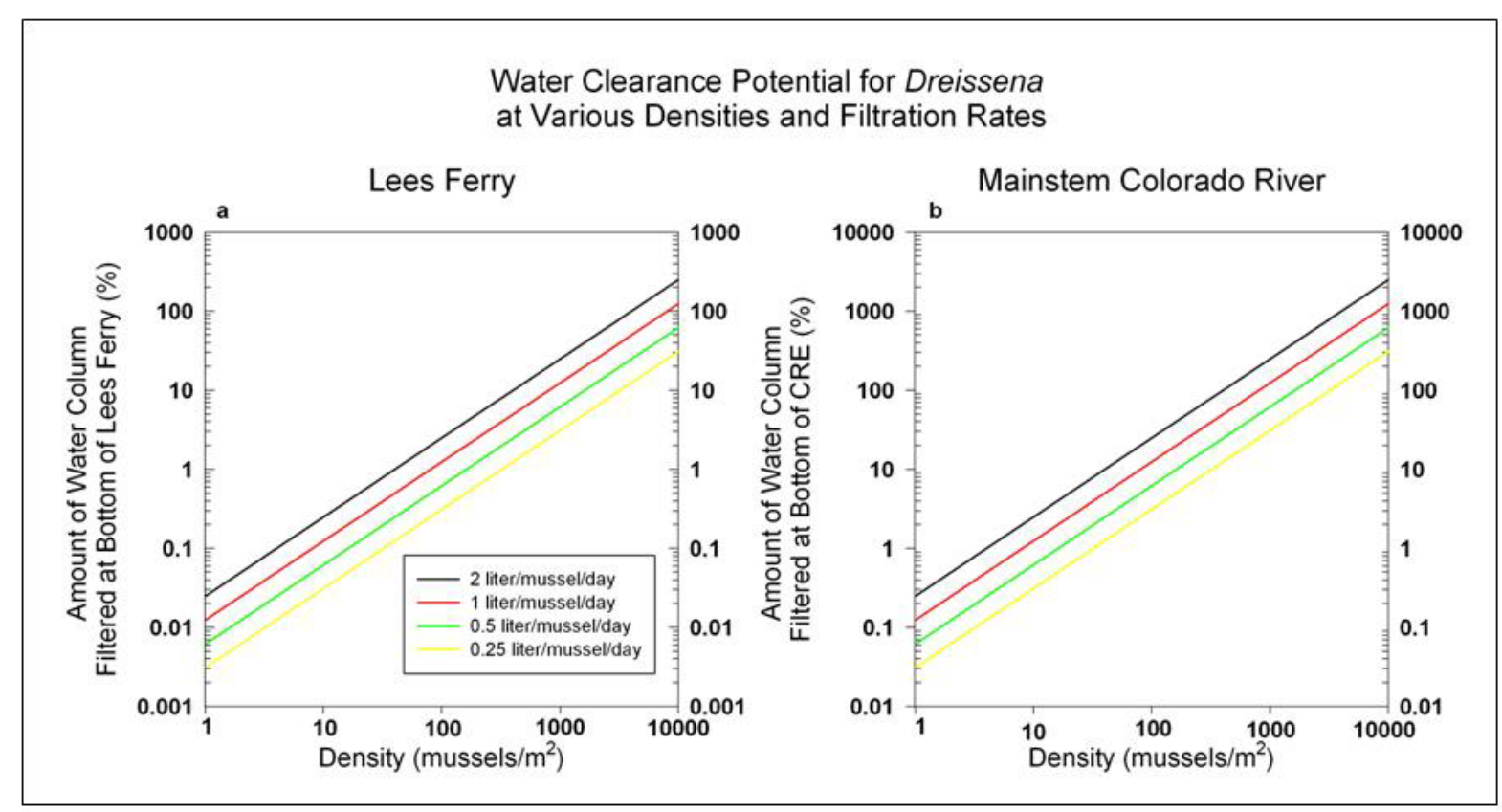

Figure 3. Water clearance potential for Dreissena at various densities and filtration rates for Lees Ferry and mainstem Colorado River ecosystem (CRE). Lines represent the percentage of the water column that Dreissena have filtered when the water arrives at the bottom end of the Lees Ferry reach (a) or at the bottom end of the CRE (b). Calculations follow the methods of Strayer and others (1998) as follows: The product of individual filtration rates $\left(\mathrm{m}^{3} / \mathrm{d}\right)$ and mussel density $\left(\# / \mathrm{m}^{2}\right)$ is the populations' clearance rate $(\mathrm{m} / \mathrm{d})$. This represents the depth of water $(\mathrm{m})$ that a population of mussels can filter in a day. The product of clearance rate and average depth of the CRE, which I assume to be $4 \mathrm{~m}$, is the proportion of the CRE that a population of mussels will filter in a day. Multiplying this value by typical travel times (dam to Lees Ferry $=0.5 \mathrm{~d}$ and dam to Diamond Creek = $5 \mathrm{~d}$, Graf, 1995) yields the proportion of the water column a population of mussels will have filtered when it arrives at each location. Note the $\log 10 x$ and $y$-axis.

\section{In situ Impacts of Dreissena in the Colorado River Ecosystem}

It is unlikely that Dreissena within the CRE will have any major impacts on the CRE because the high sediment loads, the high I:O ratios, and the high water velocities will almost certainly prevent Dreissena from attaining high densities. Nonetheless, a very liberal estimate of possible Dreissena density in the CRE is $100 / \mathrm{m}^{2}$. If we use the same individual filtration rate as 
above, $0.6 \mathrm{~L} / \mathrm{mussel} / \mathrm{d}$, we see that by the time a parcel of water arrives at Diamond Creek, Dreissena will have filtered $\sim 6.5 \%$ of the water column. As with Lees Ferry, it seems like the only impact this can have on the CRE is to increase food resources for fishes.

\section{Risk of Dreissena Introduction to Tributaries}

Dreissena are unlikely to be introduced to tributaries because there are no good vectors to transport veligers or adults. Introduction of Dreissena to tributaries will require an upstream source of veligers or a vector that can transport them upstream from the CRE should Dreissena colonize the CRE, and maintenance of populations in tributaries will require a continuous supply of veligers from either of these two potential sources. Lake Powell will undoubtedly provide the upriver population of Dreissena needed to support and maintain populations in the CRE.

Introductions of Dreissena veligers or adults from upstream sources within tributaries are unlikely because tributaries generally lack impoundments or lakes that could support self-recruiting populations. In fact, the only tributary that has any sizable upstream reservoirs is the Little Colorado River, but these impoundments are far up in the watershed. Further, the segment of river between these impoundments and where the Little Colorado River meets the CRE is ephemeral and only contains water during times of flooding, when any veligers or adults present would be expected to be killed or damaged because of turbulence or other physical forces associated with a flood.

If the CRE mainstem is colonized by Dreissena, then larvae or adults could be transported upstream into the tributaries if vectors existed, but they are absent. Anglers regularly move between the CRE and Bright Angel Creek, and hikers regularly move between the mainstem CRE and all tributaries. But anglers or hikers are unlikely to transport veligers or adults very far up tributaries and they are unlikely to transport the large number of veligers or adults required to maintain a population of Dreissena in an environment with continual downstream flow.

\section{Conclusions and Recommendations}

It is obviously prudent to do everything possible to prevent the introduction of nonnative species, particularly ones such as Dreissena that have had major economic and ecological impacts. However, the above assessment indicates that the introduction of Dreissena to the CRE does not appear to pose a great risk to Lees Ferry, the CRE mainstem, or its tributaries. Although Dreissena will probably establish at moderate densities in Lees Ferry, it appears that the ecological impact will be an increase in algae and invertebrate production. The combination of high suspendedsediment concentrations, high I:O ratios, high water velocity, and turbulence in rapids make it unlikely that Dreissena will establish at even moderate densities in the CRE or its tributaries. Even if this does occur, it appears the ecological impacts will also be an increase in algae and invertebrate production. Dreissena will undoubtedly become established in Lake Powell, but it does not appear that they will substantially alter the composition of water released from Glen Canyon Dam. If the composition of water released from Glen Canyon Dam is altered by Dreissena populations in Lake Powell (increase in dissolved nutrients and water clarity, decrease in phytoplankton and zooplankton concentrations), it is unclear how this will impact the CRE, but it will likely stimulate algae, and presumably invertebrate, production in Lees Ferry.

Maintenance of Dreissena populations in a stream or river requires the presence of upriver sites that support self-recruiting populations of Dreissena that can serve as a source for veligers (Stoeckel and others, 2004); without an upriver source of veligers, a population of Dreissena will 
be continually displaced downriver. Lake Powell will eventually become this upriver source population.

With the discovery of Dreissena in Lake Mead for the first time in January 2007, prevention of further introductions is a logical focus for management. Preventing introduction of Dreissena to Lake Powell, and preventing spread of Dreissena from Lake Powell to other watersheds and upriver within the Colorado River watershed, would parallel initial approaches to exotic species invasion taken elsewhere in the United States. Preventing or delaying the eventual introduction of Dreissena to Lake Powell will give scientists time to better estimate potential impacts of a Dreissena invasion on Lake Powell and how changes in Lake Powell water quality will affect the CRE. If Lake Powell eventually supports a large population of Dreissena, it may serve as a source for Dreissena spread throughout the Western United States because of the large number of recreational watercraft that are transported from Lake Powell to other watersheds or upstream within the watershed.

Research efforts might focus on estimating potential maximum density and distribution of Dreissena within Lake Powell and estimating the types and magnitude of changes in Lake Powell water quality that may occur. Lake Powell is relatively unproductive (Vernieu and others, 2005) and large portions of Lake Powell may prove unsuitable for Dreissena because of low dissolved oxygen concentrations in the hypolimnion (Alexander and McMahon, 2004; Karatayev and others, 1998); both of these factors may limit the eventual density and total population size of Dreissena, which will limit its potential for ecological impacts there. Because Lake Powell is thermally stratified throughout the year, Dreissena will not have access to the entire water column; this will further limit its potential for large ecological impacts (MacIsaac, 1996; Yu and Culver, 1999).

\section{References Cited}

Ackerman, J.D., 1999, Effect of velocity on the filter feeding of dreissenid mussels (Dreissena polymorpha and Dreissena bugensis): implications for trophic dynamics: Canadian Journal of Fisheries and Aquatic Sciences, v. 56, no. 9, p. 1551-1561.

Alexander, J.E., and McMahon, R.F., 2004, Respiratory response to temperature and hypoxia in the zebra mussel Dreissena polymorpha: Comparative Biochemistry and Physiology A-Molecular \& Integrative Physiology, v. 137, no. 2, p. 425-434.

Allen, Y.C., and Ramcharan, C.W., 2001, Dreissena distribution in commercial waterways of the US: using failed invasions to identify limiting factors: Canadian Journal of Fisheries and Aquatic Sciences, v. 58, no. 5, p. 898-907.

Allen, Y.C., Thompson, B.A., and Ramcharan, C.W., 1999, Growth and mortality rates of the zebra mussel, Dreissena polymorpha, in the Lower Mississippi River: Canadian Journal of Fisheries and Aquatic Sciences, v. 56, no. 5, p. 748-759.

Angradi, T.R., 1994, Trophic linkages in the lower Colorado River - multiple stable isotope evidence: Journal of the North American Benthological Society, v. 13, no. 4, p. 479-495.

Beekey, M.A., McCabe, D.J., and Marsden, J.E., 2004, Zebra mussel colonisation of soft sediments facilitates invertebrate communities: Freshwater Biology, v. 49, no. 5, p. 535-545.

Bially, A., and MacIsaac, H.J., 2000, Fouling mussels (Dreissena spp.) colonize soft sediments in Lake Erie and facilitate benthic invertebrates: Freshwater Biology, v. 43, no. 1, p. 85-97.

Bobeldyk, A.M., Bossenbroek, J.M., Evans-White, M.A., Lodge, D.M., and Lamberti, G.A., 2005, Secondary spread of zebra mussels (Dreissena polymorpha) in coupled lake-stream systems: Ecoscience, v. 12, no. 3, p. 339-346. 
Botts, P.S., Patterson, B.A., and Schloesser, D.W., 1996, Zebra mussel effects on benthic invertebrates: physical or biotic? Journal of the North American Benthological Society, v. 15, no. 2, p. 179-184.

Graf, J.B., 1995, Measured and predicted velocity and longitudinal dispersion at steady and unsteady-flow, Colorado River, Glen Canyon Dam to Lake Mead: Water Resources Bulletin, v. 31, no. 2, p. 265-281.

Greenwood, K.S., Thorp, J.H., Summers, R.B., and Guelda, D.L., 2001, Effects of an exotic bivalve mollusc on benthic invertebrates and food quality in the Ohio River: Hydrobiologia, v. 462, p. 169-172.

Horvath, T.G., and Lamberti, G.A., 1999, Mortality of zebra mussel, Dreissena polymorpha, veligers during downstream transport: Freshwater Biology, v. 42, no. 1, p. 69-76.

Horvath, T.G., Lamberti, G.A., Lodge, D.M., and Perry, W.L., 1996, Zebra mussel dispersal in lake-stream systems: source-sink dynamics? Journal of the North American Benthological Society, v. 15, no. 4, p. 564-575.

Johnson, L.E., Ricciardi, A., and Carlton, J.T., 2001, Overland dispersal of aquatic invasive species: a risk assessment of transient recreational boating: Ecological Applications, v. 11, no. 6, p. 1789-1799.

Karatayev, A.Y., Burlakova, L.E., and Padilla, D.K., 1998, Physical factors that limit the distribution and abundance of Dreissena polymorpha (Pall.): Journal of Shellfish Research, v. 17, no. 4, p. 1219-1235.

Kieffer, S.W., 1987, The rapids and waves of the Colorado River, Grand Canyon: Glen Canyon Environmental Studies, Flagstaff, Ariz., 111 p.

Korn, J., and Vernieu, W.S., 1998, Mainstem and tributary temperature monitoring in Grand Canyon, AZ: Grand Canyon Monitoring and Research Center, Flagstaff, Ariz., 48 p.

Leung, B., Bossenbroek, J.M., and Lodge, D.M., 2006, Boats, pathways, and aquatic biological invasions: estimating dispersal potential with gravity models: Biological Invasions, v. 8, no. 2, p. 241-254.

MacIsaac, H.J., 1996, Potential abiotic and biotic impacts of zebra mussels on the inland waters of North America: American Zoologist, v. 36, no. 3, p. 287-299.

MacIsaac, H.J., and Rocha, R., 1995, Effects of suspended clay on zebra mussel (Dreissenapolymorpha) feces and pseudofaeces production: Archiv Für Hydrobiologie, v. 135, no. 1, p. 5364.

Madon, S.P., Schneider, D.W., Stoeckel, J.A., and Sparks, R.E., 1998, Effects of inorganic sediment and food concentrations on energetic processes of the zebra mussel, Dreissena polymorpha: implications for growth in turbid rivers: Canadian Journal of Fisheries and Aquatic Sciences, v. 55, no. 2, p. 401-413.

McKinney, T., and Speas, D.W., 2001, Observations of size-related asymmetries in diet and energy intake of rainbow trout in a regulated river: Environmental Biology of Fishes, v. 61, p. 435-444.

Rehmann, C.R., Stoeckel, J.A., and Schneider, D.W., 2003, Effect of turbulence on the mortality of zebra mussel veligers: Canadian Journal of Zoology/Revue Canadienne De Zoologie, v. 81, no. 6, p. 1063-1069.

Ricciardi, A., Neves, R.J., and Rasmussen, J.B., 1998, Impending extinctions of North American freshwater mussels (Unionoida) following the zebra mussel (Dreissena polymorpha) invasion: Journal of Animal Ecology, v. 67, no. 4, p. 613-619.

Schneider, D.W., Madon, S.P., Stoeckel, J.A., and Sparks, R.E., 1998, Seston quality controls zebra mussel (Dreissena polymorpha) energetics in turbid rivers: Oecologia, v. 117, no. 3, p. 331-341. 
Schneider, D.W., Stoeckel, J.A., Rehmann, C.R., Blodgett, K.D., Sparks, R.E., and Padilla, D.K., 2003, A developmental bottleneck in dispersing larvae: implications for spatial population dynamics: Ecology Letters, v. 6, no. 4, p. 352-360.

Spidle, A.P., Mills, E.L., and May, B., 1995, Limits to tolerance of temperature and salinity in the quagga mussel (Dreissena bugensis) and the zebra mussel (Dreissena polymorpha): Canadian Journal of Fisheries and Aquatic Sciences, v. 52, no. 10, p. 2108-2119.

Sprung, M., 1993, The other life: an account of present knowledge of the larval phase of Dreissena polymorpha, in Nalepa, T.F., and Schloesser, D.W., eds., Zebra mussels: biology, impacts, and control: Boca Raton, Fla., CRC Press, p. 39-54.

Stewart, T.W., Miner, J.G., and Lowe, R.L., 1998, Macroinvertebrate communities on hard substrates in western Lake Erie: structuring effects of Dreissena: Journal of Great Lakes Research, v. 24, no. 4, p. 868-879.

Stoeckel, J.A., Rehmann, C.R., Schneider, D.W., and Padilla, D.K., 2004, Retention and supply of zebra mussel larvae in a large river system: importance of an upstream lake: Freshwater Biology, v. 49, no. 7, p. 919-930.

Strayer, D.L., Caraco, N.F., Cole, J.J., Findlay, S., and Pace, M.L., 1999, Transformation of freshwater ecosystems by bivalves - a case study of zebra mussels in the Hudson River: Bioscience, v. 49, no. 1, p. 19-27.

Strayer, D.L., Hattala, K.A., and Kahnle, A.W., 2004, Effects of an invasive bivalve (Dreissena polymorpha) on fish in the Hudson River estuary: Canadian Journal of Fisheries and Aquatic Sciences, v. 61, no. 6, p. 924-941.

Strayer, D.L., and Malcom, H.M., 2007, Effects of zebra mussels (Dreissena polymorpha) on native bivalves: the beginning of the end or the end of the beginning?: Journal of the North American Benthological Society, v. 26, no. 1, p. 111-122.

Strayer, D.L., Smith, L.C., and Hunter, D.C., 1998, Effects of the zebra mussel (Dreissena polymorpha) invasion on the macrobenthos of the freshwater tidal Hudson River: Canadian Journal of Zoology-Revue Canadienne De Zoologie, v. 76, no. 3, p. 419-425.

Thorp, J.H., Alexander, J.E., Bukaveckas, B.L., Cobbs, G.A., and Bresko, K.L., 1998, Responses of Ohio River and Lake Erie dreissenid molluscs to changes in temperature and turbidity: Canadian Journal of Fisheries and Aquatic Sciences, v. 55, no. 1, p. 220-229.

Trefry, J.H., Metz, S., Nelsen, T.A., Trocine, R.P., and Eadie, B.J., 1994, Transport of particulate organic-carbon by the Mississippi River and its fate in the Gulf-of-Mexico: Estuaries, v. 17, no. 4, p. 839-849.

Vernieu, W.S., Hueftle, S.J., and Gloss, S.P., 2005, Water quality in Lake Powell and the Colorado River, in Gloss, S.P., Lovich, J.E., and Melis, T.S., eds., The state of the Colorado River ecosystem in Grand Canyon: U.S. Geological Survey Circular 1282, p. 69-85.

Wetzel, R.G., 2001, Limnology (3rd ed.): San Diego, CA, Academic Press, 1006 p.

Yard, M.D., 2003, Light availability and aquatic primary production: Colorado River, Glen and Grand Canyons, AZ: Flagstaff, Northern Arizona University, Ph.D.

Yu, N., and Culver, D.A., 1999, Estimating the effective clearance rate and refiltration by zebra mussels, Dreissena polymorpha, in a stratified reservoir: Freshwater Biology, v. 41, no. 3, p. 481-492. 